\title{
Nitrate Uptake and Nitrogen Use Efficiency by Kentucky Bluegrass Cultivars
}

\author{
Zhongchun Jiang ${ }^{1}$, W. Michael Sullivan ${ }^{2}$, and Richard J. Hull ${ }^{3}$ \\ Department of Plant Sciences, University of Rhode Island, Kingston, \\ RI 02881-0804
}

Additional index words. Poa pratensis, root morphology, nitrogen partitioning, genotypic variation, temporal variation

\begin{abstract}
Efficient utilization of fertilizer-nitrogen ( $N$ ) by turfgrasses is probably related to $\mathrm{N}$ uptake efficiency of roots and metabolic efficiency of absorbed $\mathrm{N}$ in roots and shoots. This study evaluated Kentucky bluegrass (Poa pratensis L.) cultivars for potential differences in nitrate uptake rate (NUR), temporal variation in NUR, and the relationship between NUR and $\mathrm{N}$ use efficiency (NUE), defined as grams dry matter per gram $\mathrm{N}$. Six cultivars were propagated from tillers of seeded plants, grown in silica sand, mowed weekly, and watered daily with a complete nutrient solution containing $1.0 \mathrm{~mm}$ nitrate. A nutrient depletion method from an initial nitrate concentration of $0.5 \mathrm{~mm}$ was used to determine NUR of 5 -month-old plants. NUR $\left(\mu \mathrm{mol} \cdot \mathrm{h}^{-1}\right.$ per plant) of the six cultivars ranked as follows: 'Blacksburg' > 'Conni' > 'Dawn' > 'Eclipse' = 'Barzan' > 'Gnome'. When NUR was based on root weight, 'Conni' ranked highest; when NUR was based on root length, surface, or volume, 'Eclipse' ranked highest. Averaged across cultivars, NUR on the second day was greater than NUR for the first day of nitrate exposure. Temporal variation was greatest in 'Blacksburg', while none was noted in 'Conni' or 'Eclipse'. Cultivar differences in NUE were significant in fibrous roots, rhizomes, and leaf sheaths, but not in leaf blades and thatch. Total nitrate uptake was positively related to total $\mathbf{N}$ recovered and total plant dry matter, but NUR based on root weight was negatively correlated with NUE of the whole plant.
\end{abstract}

Turfgrass cultivars that have superior ability to absorb and utilize nitrate are needed for a sustainable turf. Information on temporal variation in nitrate absorption is also needed to enhance the environmental safety of turfgrass $\mathrm{N}$ fertilization programs. Efficient use of fertilizer-nitrogen $(\mathrm{N})$ by turfgrasses is probably related to $\mathrm{N}$ uptake efficiency of roots and metabolic use efficiency of absorbed $\mathrm{N}$ in roots and shoots. In Kentucky bluegrass, $\mathrm{N}$ use efficiency (NUE), expressed as dry matter per unit of total $\mathrm{N}$ in clippings, decreased as nitrate uptake rate (NUR) increased in response to increasing ambient nitrate levels (Jiang and Hull, 1998). However, this negative relationship between NUE and NUR may not hold when NUE is determined based on entire plants, including roots and rhizomes. Presumably, the negative relationship should persist because, as NUR increases with increasing nitrate supply, more nitrate will probably be translocated to shoots, where enhanced nitrate metabolism

Received for publication 8 Oct. 1999. Accepted for publication 8 Mar. 2000. Journal paper no. 3760 of the Rhode Island Agricultural Experiment Station, Kingston, RI 02881. We thank Carl D. Sawyer and Mary Philcox for their assistance. The cost of publishing this paper was defrayed in part by the payment of page charges. Under postal regulations, this paper therefore must be hereby marked advertisement solely to indicate this fact.

${ }^{1}$ Post-Doctoral Research Associate. E-mail address: zjiang@etal.uri.edu.

${ }^{2}$ Professor.

${ }^{3}$ Professor tends to inhibit dry matter partitioning to roots (McDonald et al., 1996).

Intraspecific differences in NUE, as defined by tissue dry matter per unit $\mathrm{N}$ present in the tissue, have been demonstrated in shoots and roots of Kentucky bluegrass grown under greenhouse conditions (Bertauski et al., 1997; Jiang and Hull, 1998). In those studies, plants were young, within $60 \mathrm{~d}$ after seeding, and produced no rhizomes. Kentucky bluegrass is a strongly rhizomatous species and cultivar differences in rhizome production have been demonstrated (Ensign and Weiser, 1975). The effect of differential rhizome production on NUE of the whole plant has not been ascertained. Under field conditions, clippings collected from six cultivars of 4-year-old Kentucky bluegrass turf showed no differences in N concentration or NUE (Liu et al., 1993). However, differences in nitrate uptake properties were demonstrated among those cultivars. NUE of shoots and roots of mature turfgrasses may differ from that of young grasses, and intraspecific differences in NUR may contribute to intraspecifc differences in NUE of the whole plant.

Most determinations of NUR in turfgrasses have been based on nitrate depletion during 0.25- to 8-h intervals (Bowman et al., 1989; Liu et al., 1993). When net nitrate uptake is determined by this method over a short period of time during the day, the rates obtained represent a maximum capacity of nitrate uptake by the roots because net uptake rates are lower during the night (Bowman et al., 1989;
Cárdenas-Navarro et al., 1998). When determined on a daily basis, NUR should more closely approximate uptake rates by plants grown under field conditions. Furthermore, temporal fluctuations of nitrate levels often occur under field conditions (Duff et al., 1997; Liu et al., 1997). Effects of these fluctuations on NUR and intraspecific differences in the response of NUR to these fluctuations have not been ascertained in Kentucky bluegrass.

The objectives of this study were to determine: 1) differences in NUR on a daily basis among selected Kentucky bluegrass cultivars; 2) NUR responses in these cultivars to fluctuations in nitrate levels; and 3) the relationship between NUR and NUE of the whole plant. Particular attention was given to contributions of the belowground plant organs, including roots and rhizomes.

\section{Materials and Methods}

Plant culture. Six cultivars of Kentucky bluegrass were selected based on 5-year means of turfgrass quality ratings in field trials of the United States National Turfgrass Evaluation Program (NTEP, 1996). Cultivars Blacksburg and Eclipse were among the top performers (5-year mean quality ratings $=6.0 ; \mathrm{LSD}=0.2$ at $P \leq 0.05)$ followed by 'Conni' (5.7), 'Dawn' (5.7), 'Gnome' (5.4), and 'Barzan' (5.2). Seedlings were transferred to growth flats containing a soil-perlite mixture with seedlings planted in individual cells $30 \mathrm{~d}$ after seeding. Three and one-half months later, six tillers were separated from the seed-generated plant with the largest number of tillers. These clonal tillers were planted in individual polystyrene containers $(3.8-\mathrm{cm}$ diameter, $21-\mathrm{cm}$ depth, one bottom and four side drainage holes; Stuewe \& Sonc, Corvalis, Ore.) filled with silica sand. They were placed in a greenhouse and irrigated daily with a one-half strength, $\mathrm{N}$ free Hoagland's solution (Hoagland and Arnon, 1950), supplemented with $1 \mathrm{~mm} \mathrm{NaNO}_{3}$. Grasses were clipped once every week to a 5$\mathrm{cm}$ height. After 5 months of growth and maintenance, tiller-generated plants completely filled their containers with five to ten new tillers. The four largest plants of each cultivar were selected for the nitrate uptake experiment.

Nitrate uptake measurement. Grasses were clipped to a height of $5 \mathrm{~cm}$ and irrigated with $20 \mathrm{~mL}$ of tap water $3 \mathrm{~d}$ before nitrate uptake measurements. Plants were excavated from polystyrene containers and roots of each plant were gently washed under running tap water for 5 min to completely remove sand $1 \mathrm{~d}$ before uptake measurements. The plants were supported by cotton plugs, in individual $130-\mathrm{mL}$ growth vessels with roots submerged in 120 $\mathrm{mL}$ of tap water, and transferred to a walk-in growth chamber. After $24 \mathrm{~h}$ in tap water (day 0), each plant was supplied with $120 \mathrm{~mL}$ of a one-half strength nutrient solution containing $0.5 \mathrm{~mm} \mathrm{NaNO}$. During solution replacement, roots were gently rinsed twice in 8 $\mathrm{L}$ of the same solution to prevent dilution of the uptake medium. The solution in each growth 
vessel was continuously aerated through an aeration line connected to an air pump via a manifold. The atmosphere of the growth chamber was circulated via a built-in electric fan. The temperatures in the chamber were $24{ }^{\circ} \mathrm{C}$ day $/ 15^{\circ} \mathrm{C}$ night, and the photosynthetic photon flux $(P P F)$ density at plant height was $800 \mu \mathrm{mol} \cdot \mathrm{m}^{-2} \cdot \mathrm{s}^{-1}$ with a photoperiod of $14 \mathrm{~h}$. After the plants had been in the nutrient solution for $24 \mathrm{~h}$, a $2-\mathrm{mL}$ sample of the solution was taken from each growth vessel and the volume of the remaining solution was recorded to determine nitrate depletion. The nutrient solution was replaced and the procedure was repeated each day over an 8-d period, with the nutrient solution being replaced by tap water on day 6 . Nitrate concentration was determined using a rapid-flow analyzer (RFA 300; ALPKEM Corp., Clackamas, Ore.). Net nitrate uptake was calculated from nitrate depletion data.

Root quantification. After nitrate uptake measurements, the plants were separated into six parts: leaf blades, sheaths, dead but attached leaves (thatch), rhizomes, fibrous roots, and adventitious roots. All plant parts except thatch were scanned on a scanner (ScanJet 4c, Hewlett-Packard Co., Palo Alto, Calif.) contained in a Delta-T SCAN Splash Protection System (Delta-T Devices, Cambridge, England). Fibrous root systems were cut into five portions along their longitudinal axes and root pieces were completely spread in Delta-T SCAN root handling dishes containing a 3mm layer of deionized water. Water facilitated the dispersal and separation of fibrous roots. The dish, which has a transparent glass bottom, was placed on the scanner and covered with an opaque, white cover. Because fibrous roots were brown, they were scanned with a white background and without staining. The fibrous root samples were spread and scanned three times. Scanned images were recorded as black-and-white line drawings and saved in an uncompressed, tagged image file format to make the images compatible for analysis with Delta-T SCAN image analysis software (DeltaT Devices). The total length, total image area, and average thickness of a sample were calculated simultaneously by the Length analysis function, based on a procedure described by Harris and Campbell (1989). In addition, image files of fibrous roots were analyzed by the Length $\operatorname{Sin} \theta$ function, which estimates length distribution among specified thickness ranges by using trigonometric functions (Delta-T SCAN User Manual; Delta-T Devices, 1993). The total surface area and total volume in each thickness group were calculated by the Length $\operatorname{Sin} \theta$ function, which assumed that roots are cylindrical.

Total $N$ determination. After scanning, the weights of all plant parts were recorded both before and after oven-drying at $70^{\circ} \mathrm{C}$ for $3 \mathrm{~d}$. Total $\mathrm{N}$ content of each plant part was determined in dried tissue samples by means of a semimicro-Kjeldahl procedure (Eastin, 1978).

Data analysis. A randomized completeblock design was used with four replicates. Cultivar means of fibrous root parameters were determined with 3 images and 4 repli- cates (12 observations). Data were analyzed by analysis of variance (ANOVA) procedure and significant means were separated by Duncan's multiple range test (DUNCAN) or least significant difference (LSD) procedure within the Statistical Analysis System (SAS for Windows v. 6.12, SAS Institute, Cary, N.C.). Regression analysis was performed using the Minitab statistical analysis software (Minitab for Windows rel. 12; Minitab, State College, Pa.).

\section{Results and Discussion}

Nitrate uptake. Cumulative nitrate uptake of all cultivars increased almost linearly with time of nitrate supply, except on day 7, which followed a day when tap water containing $\leq 0.05 \mathrm{~mm}$ nitrate-N, instead of nutrient solution containing $0.5 \mathrm{~mm}$ nitrate, was supplied to the plants (Fig. 1). Cultivar differences in accumulative uptake also increased with time and were consistent over the experimental

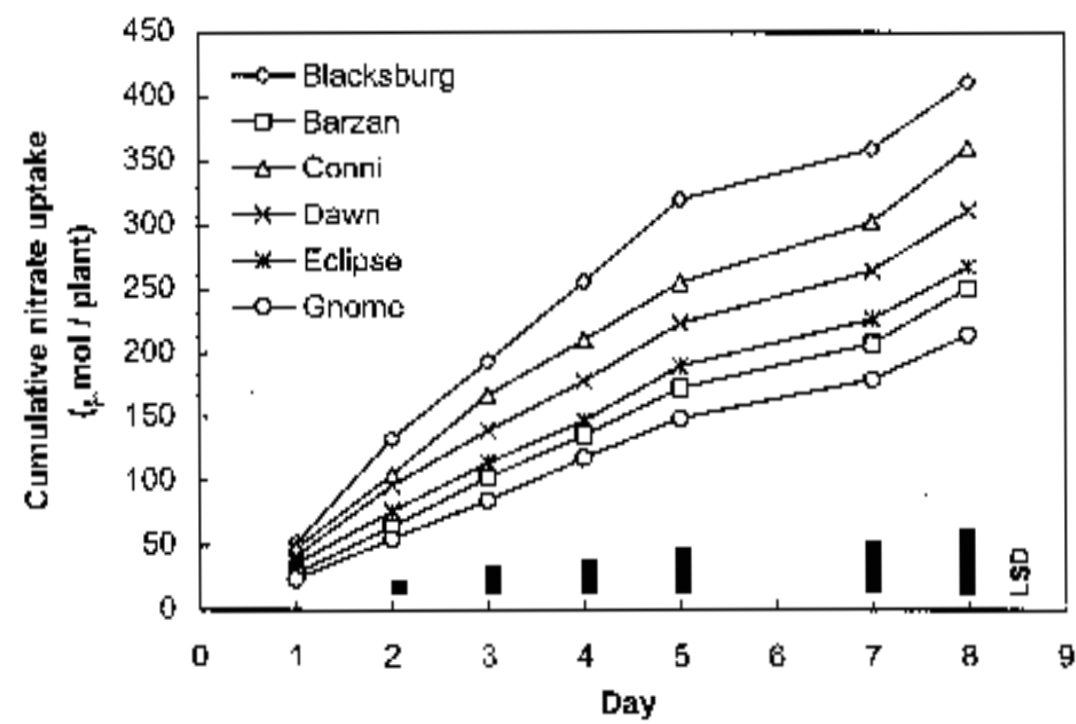

Fig. 1. Cumulative nitrate uptake by six Kentucky bluegrass cultivars. Nitrate uptake was monitored in 120 $\mathrm{mL}$ of a nutrient solution containing $0.5 \mathrm{~mm}$ nitrate, replaced at 24-h intervals for eight consecutive days. On days 0 and 6 , tap water containing $\leq 0.05 \mathrm{~mm}$ nitrate was provided instead of the nutrient solution. Bars represent least significant difference (LSD), $P \leq 0.05$, for the day indicated. LSD bar on Day 1 is not shown because of small value $(9 \mu \mathrm{mol})$.

Table 1 . Genotypic and temporal variations of nitrate uptake rate $\left(\mu \mathrm{mol} \cdot \mathrm{h}^{-1}\right.$ per plant) among six Kentucky bluegrass cultivars.

\begin{tabular}{|c|c|c|c|c|c|c|c|}
\hline \multirow[b]{2}{*}{ Day $^{z}$} & \multicolumn{7}{|c|}{ Cultivar } \\
\hline & Blacksburg & Barzan & Connie & Dawn & Eclipse & Gnome & $\overline{\text { Mean }}$ \\
\hline 1 & $2.17 \mathrm{c} \mathrm{A}^{\mathrm{y}}$ & $1.19 \mathrm{~b} \quad \mathrm{DE}$ & $2.01 \mathrm{a} A B$ & $1.75 \mathrm{ab} \mathrm{BC}$ & $1.51 \mathrm{a} C D$ & $1.01 \mathrm{~b} \quad \mathrm{E}$ & $1.61 \mathrm{~d}$ \\
\hline 2 & $3.37 \mathrm{a} \mathrm{A}$ & $1.50 \mathrm{ab} C$ & 2.38 a B & $2.27 \mathrm{a} \quad \mathrm{B}$ & $1.70 \mathrm{a} B C$ & $1.30 \mathrm{ab} \mathrm{C}$ & $2.09 \mathrm{a}$ \\
\hline 3 & $2.51 \mathrm{~b} \mathrm{~A}$ & $1.61 \mathrm{ab} B$ & $2.60 \mathrm{a} \mathrm{A}$ & $1.80 \mathrm{ab} \mathrm{B}$ & 1.59 a B & $1.26 \mathrm{ab} \mathrm{B}$ & $1.89 \mathrm{ab}$ \\
\hline 4 & $2.61 \mathrm{~b} \mathrm{~A}$ & $1.37 \mathrm{ab} B$ & 1.77 a B & $1.61 \mathrm{~b} \quad \mathrm{~B}$ & $1.36 \mathrm{a} \mathrm{B}$ & $1.38 \mathrm{ab} \mathrm{B}$ & $1.68 \mathrm{~cd}$ \\
\hline 5 & $2.68 \mathrm{~b} \mathrm{~A}$ & $1.52 \mathrm{ab} \mathrm{BC}$ & $1.88 \mathrm{a} \mathrm{B}$ & $1.86 \mathrm{ab} \mathrm{B}$ & $1.77 \mathrm{a} B$ & $1.29 \mathrm{ab} \mathrm{C}$ & $1.83 \mathrm{bc}$ \\
\hline 7 & $1.63 \mathrm{~d} \mathrm{AB}$ & $1.44 \mathrm{ab} B$ & $1.97 \mathrm{a} A$ & $1.72 \mathrm{ab} \mathrm{AB}$ & $1.53 \mathrm{a} \mathrm{AB}$ & $1.25 \mathrm{ab} \mathrm{B}$ & $1.59 \mathrm{~d}$ \\
\hline 8 & $2.16 \mathrm{c} \mathrm{AB}$ & $1.80 \mathrm{a} \quad \mathrm{BC}$ & $2.41 \mathrm{a} \mathrm{A}$ & $1.94 \mathrm{ab} \mathrm{ABC}$ & $1.71 \mathrm{a} \mathrm{BC}$ & $1.46 \mathrm{a} \quad \mathrm{C}$ & $1.91 \mathrm{ab}$ \\
\hline Mean & $2.45 \quad \mathrm{~A}$ & 1.49 & $2.14 \quad \mathrm{~B}$ & 1.85 & $1.59 \mathrm{D}$ & 1.28 & \\
\hline
\end{tabular}

${ }^{\mathrm{z}}$ On days 0 and 6 , roots were immersed in tap water for $24 \mathrm{~h}$.

y Mean separation within columns (lowercase letters) and rows (uppercase letters) by Duncan's multiple range test, $P \leq 0.05$.

Table 2. Nitrate uptake rates for six Kentucky bluegrass cultivars calculated using five methods.

\begin{tabular}{|c|c|c|c|c|c|}
\hline \multirow[b]{2}{*}{ Cultivar } & \multicolumn{5}{|c|}{ Methods $^{z}$} \\
\hline & Fresh wt & Dry wt & Length & Surface & Volume \\
\hline & \multicolumn{2}{|c|}{$\mu \mathrm{mol} \cdot \mathrm{g}^{-1} \cdot \mathrm{h}^{-1}$} & $\mathrm{nmol} \cdot \mathrm{m}^{-1} \cdot \mathrm{h}^{-1}$ & $\mathrm{nmol} \cdot \mathrm{cm}^{-2} \cdot \mathrm{h}^{-1}$ & $\mathrm{pmol} \cdot \mathrm{cm}^{-3} \cdot \mathrm{h}^{-1}$ \\
\hline Blacksburg & $2.1 \mathrm{c}^{\mathrm{y}}$ & $8.6 \mathrm{~d}$ & $56.3 \mathrm{~b}$ & $9.6 \mathrm{~b}$ & $1.0 \mathrm{~b}$ \\
\hline Barzan & $3.1 \mathrm{~b}$ & $14.3 \mathrm{~b}$ & $75.0 \mathrm{ab}$ & $15.4 \mathrm{ab}$ & $2.1 \mathrm{ab}$ \\
\hline Connie & $4.4 \mathrm{a}$ & $18.4 \mathrm{a}$ & $82.5 \mathrm{a}$ & $15.8 \mathrm{ab}$ & $2.2 \mathrm{ab}$ \\
\hline Dawn & $3.2 \mathrm{~b}$ & $13.4 \mathrm{bc}$ & $82.9 \mathrm{a}$ & $16.7 \mathrm{a}$ & $2.1 \mathrm{ab}$ \\
\hline Eclipse & $2.8 \mathrm{bc}$ & $11.6 \mathrm{bcd}$ & $91.3 \mathrm{a}$ & $18.3 \mathrm{a}$ & $2.6 \mathrm{a}$ \\
\hline Gnome & $2.5 \mathrm{bc}$ & $9.9 \mathrm{~cd}$ & $54.6 \mathrm{~b}$ & $11.3 \mathrm{~b}$ & $1.8 \mathrm{ab}$ \\
\hline
\end{tabular}

${ }^{2}$ To calculate nitrate uptake rate on different bases, the grand mean of nitrate uptake rate of an individual plant was divided by the total root fresh weight, root dry weight, root length, root surface area, or root volume of that plant.

'Mean separation within columns by Duncan's multiple range test, $P \leq 0.05$. 
period. The difference in the amount of nitrate absorbed between cultivars Blacksburg and Gnome was $28 \mu \mathrm{mol}$ on day 1 and $197 \mu \mathrm{mol}$ by the end of the experiment. Total nitrate absorbed per plant during the experiment ranked in the following order: 'Blacksburg' > 'Conni' > 'Dawn' > 'Eclipse' = 'Barzan' > 'Gnome'. When grown in sand under greenhouse conditions, 'Blacksburg' produces a fibrous root system with a total length nearly twice that of any of the other five cultivars (Sullivan et al., 2000). Taken together, these results suggest that nitrate uptake capacity could be increased if the root system was larger. Increased rooting may result in greater nitrate uptake for turfgrasses grown under field conditions because a plant with a larger root system can explore larger volumes of soil for nutrients (Boot, 1989). The larger root system and associated greater nitrate uptake ability may contribute to the superior performance of 'Blacksburg' observed in the NTEP trials, relative to other cultivars in this study.

The NUR, expressed as $\mu \mathrm{mol} \cdot \mathrm{h}^{-1}$ per plant, differed among cultivars and over time (Table 1). On days 1, 2, 3, 4, and 5, 'Blacksburg' exhibited higher uptake rates than other cultivars except 'Conni' on day 1 and day 3 . The NUR of 'Gnome', averaged across all days, was lower than that of any cultivar. On days 0 and 6 , plants were placed in tap water $(\leq 0.05$ $\mathrm{mm}$ nitrate-N), which should have promoted greater nitrate uptake on the following days (Bowman et al., 1989). Mean uptake rate, when averaged across all cultivars, was higher on day 2 than on day 1 , and on day 8 than on day 7. The expression of nitrate transporter genes in roots of 16-d-old Arabidopsis thaliana L. can be induced within $1 \mathrm{~h}$ of supplying nitrate, and the transcripts decrease after $8 \mathrm{~h}$ (Filleur and Daniel-Vedele, 1999). The plants in our study may have been slow in expressing nitrate transporter genes because of their greater age, and the genes may have been expressed largely on the second day following culture in tap water containing $\leq 0.05 \mathrm{~mm}$ nitrate-N. Temporal variation in NUR was observed for 'Blacksburg', 'Barzan', 'Dawn', and 'Gnome', but not for 'Conni' and 'Eclipse' (Table 1), indicating cultivar differences in response to fluctuating nitrate concentrations.

When calculated using different methods, NUR ranking varied among cultivars (Table 2). 'Conni' exhibited the highest NUR based on fresh or dry root weight but the values for 'Eclipse' were higher than those for 'Blacksburg' when NUR was based on root length, surface area, or volume (Table 2). These findings are consistent with earlier observations by Sullivan et al. (2000) that 'Conni' had greater and 'Eclipse' had smaller specific length, surface area, and volume per unit dry mass than did 'Blacksburg'. These results suggest that nitrate uptake is dependent on both absorptive surface and root mass. Although 'Blacksburg' absorbed the largest amount of nitrate per plant (Fig. 1) and exhibited the highest mean NUR on a per-plant basis (Table 1), it had lower NUR expressed on a root mass or root length basis than did most other cultivars (Table 2), indicating an inefficiency in
Table 3. Tissue and plant $\mathrm{N}$ use efficiency, partitioning of total $\mathrm{N}$ among plant parts, and below : aboveground $\mathrm{N}$ ratio for six Kentucky bluegrass cultivars.

\begin{tabular}{|c|c|c|c|c|c|c|c|c|}
\hline Cultivar & $\begin{array}{c}\text { Fibrous } \\
\text { root }\end{array}$ & $\begin{array}{l}\text { Advent. } \\
\text { root }\end{array}$ & Rhizome & Thatch & Sheath & Blade & Plant $^{2}$ & $\begin{array}{c}\text { Below : } \\
\text { aboveground }\end{array}$ \\
\hline & \multicolumn{7}{|c|}{$N$ use efficiency ( $g$ dry matter/g $N)$} & \\
\hline Blacksburg & $109.5 \mathrm{a}^{\mathrm{y}}$ & $56.7 \mathrm{a}$ & $85.8 \mathrm{abc}$ & $69.2 \mathrm{a}$ & $91.7 \mathrm{a}$ & $33.3 \mathrm{a}$ & $63.1 \mathrm{a}$ & --- \\
\hline Barzan & $82.9 \mathrm{c}$ & $85.1 \mathrm{a}$ & $63.2 \mathrm{~cd}$ & $64.6 \mathrm{a}$ & $51.3 \mathrm{~b}$ & $29.9 \mathrm{a}$ & $51.7 \mathrm{~b}$ & --- \\
\hline Conni & $86.0 \mathrm{bc}$ & $54.0 \mathrm{a}$ & $50.5 \mathrm{~d}$ & $73.8 \mathrm{a}$ & $47.6 \mathrm{~b}$ & $35.0 \mathrm{a}$ & $51.8 \mathrm{~b}$ & --- \\
\hline Dawn & $100.2 \mathrm{ab}$ & $74.7 \mathrm{a}$ & $69.8 \mathrm{bcd}$ & $64.0 \mathrm{a}$ & $51.3 \mathrm{~b}$ & $29.6 \mathrm{a}$ & $53.2 \mathrm{~b}$ & --- \\
\hline Eclipse & $100.1 \mathrm{ab}$ & $97.3 \mathrm{a}$ & $91.4 \mathrm{ab}$ & $62.5 \mathrm{a}$ & $54.0 \mathrm{~b}$ & 30.9 a & $56.8 \mathrm{ab}$ & --- \\
\hline \multirow[t]{2}{*}{ Gnome } & $85.8 \mathrm{bc}$ & $77.9 \mathrm{a}$ & $95.7 \mathrm{a}$ & $71.5 \mathrm{a}$ & $46.6 \mathrm{~b}$ & $31.4 \mathrm{a}$ & $54.8 \mathrm{~b}$ & --- \\
\hline & \multicolumn{7}{|c|}{ Total $N$ partitioning (\% of plant total $N)$} & \\
\hline Blacksburg & $15.8 \mathrm{a}$ & $0.9 \mathrm{~b}$ & $5.8 \mathrm{~b}$ & $20.5 \mathrm{a}$ & $14.5 \mathrm{ab}$ & $42.6 \mathrm{a}$ & --- & $0.76 \mathrm{~b}$ \\
\hline Barzan & $11.2 \mathrm{~b}$ & $0.5 \mathrm{~cd}$ & $19.2 \mathrm{a}$ & $22.3 \mathrm{a}$ & $12.0 \mathrm{~b}$ & $34.9 \mathrm{a}$ & --- & $1.20 \mathrm{a}$ \\
\hline Conni & $13.1 \mathrm{ab}$ & $1.5 \mathrm{a}$ & $12.1 \mathrm{ab}$ & $17.5 \mathrm{a}$ & $16.6 \mathrm{ab}$ & $39.2 \mathrm{a}$ & --- & $0.81 \mathrm{~b}$ \\
\hline Dawn & $12.2 \mathrm{ab}$ & $0.7 \mathrm{bc}$ & $16.5 \mathrm{a}$ & $20.0 \mathrm{a}$ & $15.5 \mathrm{ab}$ & $35.2 \mathrm{a}$ & --- & $0.99 \mathrm{ab}$ \\
\hline Eclipse & $12.6 \mathrm{ab}$ & $0.3 \mathrm{~d}$ & $11.5 \mathrm{ab}$ & $22.1 \mathrm{a}$ & $16.4 \mathrm{ab}$ & $37.1 \mathrm{a}$ & --- & $0.87 \mathrm{ab}$ \\
\hline Gnome & $16.1 \mathrm{a}$ & $0.7 \mathrm{bc}$ & $4.4 \mathrm{~b}$ & $24.0 \mathrm{a}$ & $18.0 \mathrm{a}$ & $36.8 \mathrm{a}$ & --- & $0.84 \mathrm{ab}$ \\
\hline
\end{tabular}

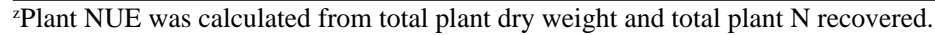

${ }^{\mathrm{y}}$ Mean separation within columns and parameters by Duncan's multiple range test, $P \leq 0.05$.
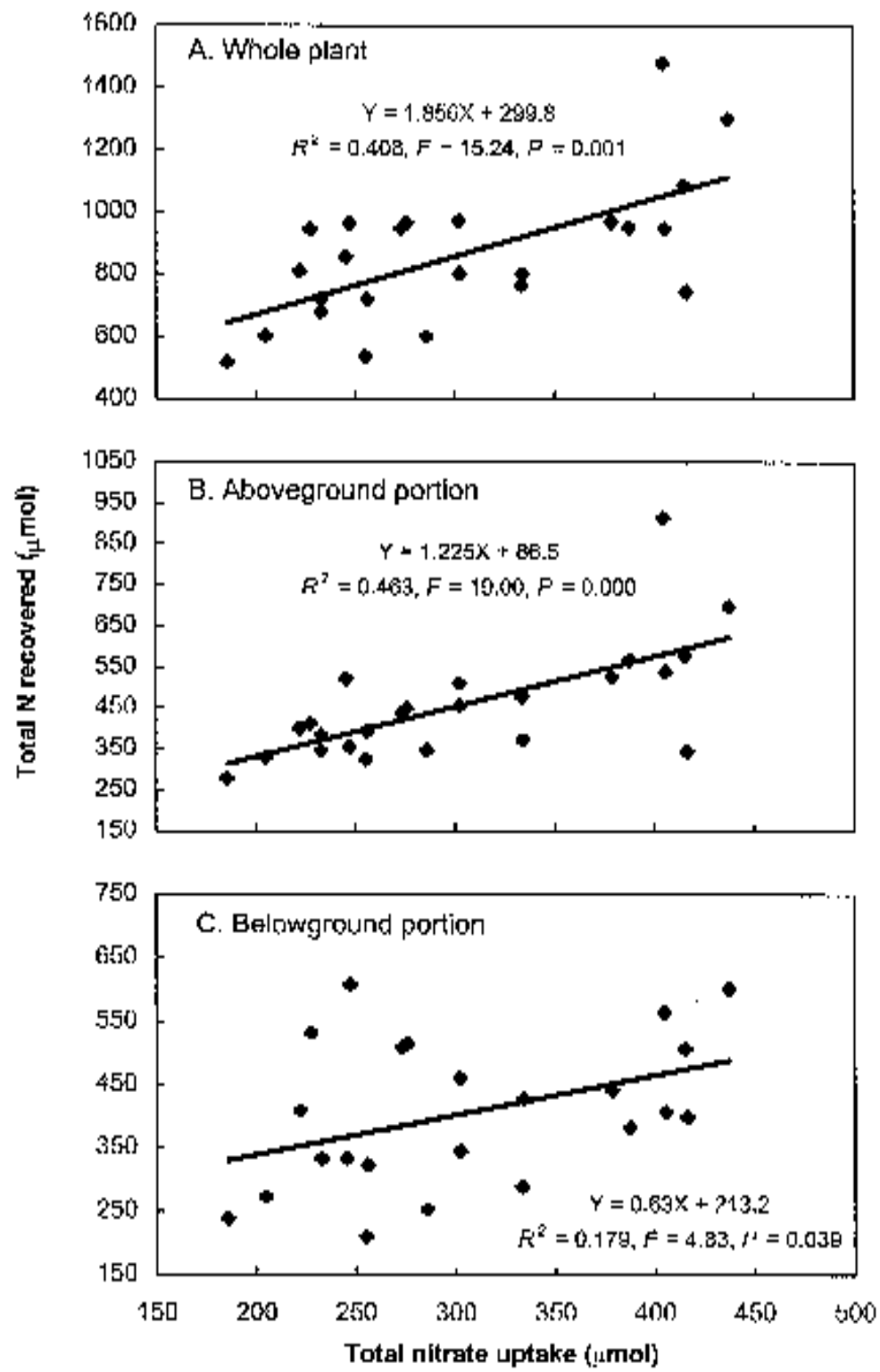

Fig. 2. Relationships between total nitrate uptake during an 8-day uptake experiment period and total $\mathrm{N}$ recovery in (A) the whole plant, (B) aboveground, and (C) belowground organs of Kentucky bluegrass. Nitrate uptake was monitored as described in Fig. 1. Aboveground portion consisted of leaf blades and sheaths, and belowground portion of thatch, fibrous roots, adventitious roots, and rhizomes. Note that scales on the Y-axis differ for $\mathbf{A}, \mathbf{B}$, and $\mathbf{C}$. 

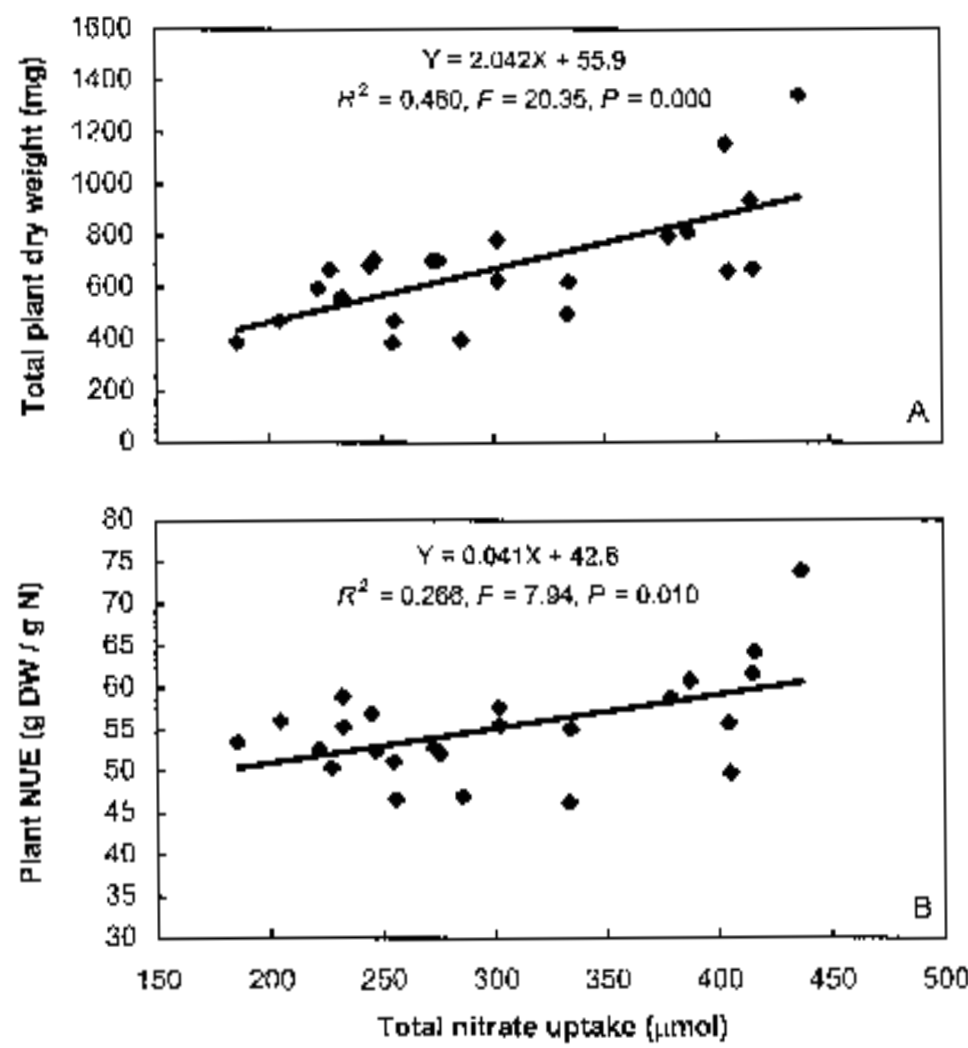

Fig. 3. Relationships between total nitrate uptake and (A) total plant dry weight and (B) plant nitrogen use efficiency in Kentucky bluegrass. Nitrate uptake was monitored as described in Fig. 1. Plant N use efficiency was expressed as grams of total plant dry matter per gram of total $\mathrm{N}$ recovered in all organs of the plant.

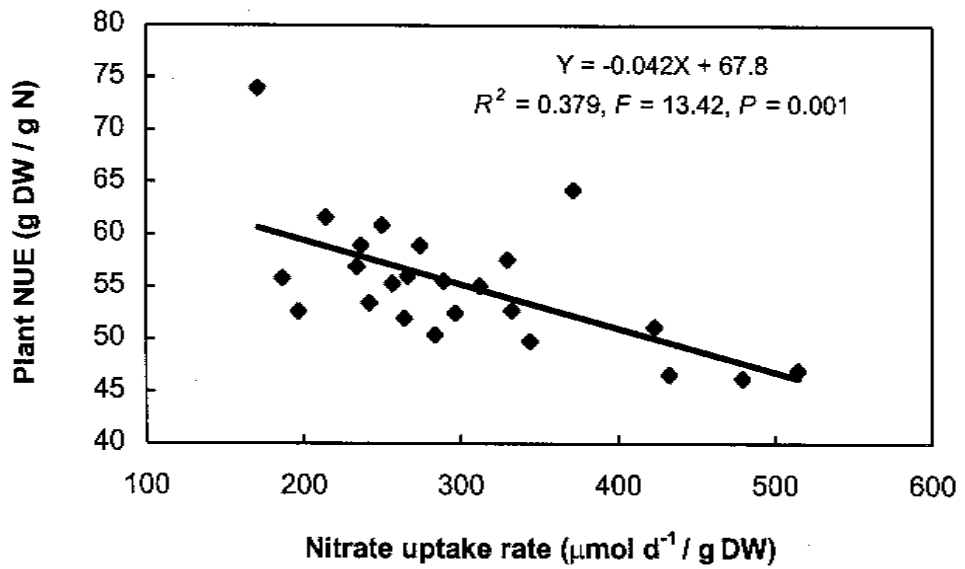

Fig. 4. Relationships between nitrate uptake rate and plant nitrogen use efficiency in Kentucky bluegrass. Nitrate uptake was monitored as described in Fig. 1, and Plant $\mathrm{N}$ use efficiency was expressed as described in Fig. 3.

nitrate absorption at the tissue level.

Nitrogen use efficiency and N partitioning. NUE, defined as grams of dry matter per gram $\mathrm{N}$ present in the tissue, has been studied primarily using turfgrass clippings. While the efficiency of $\mathrm{N}$ utilization by leaves is important, NUE of the belowground organs is particularly critical for turfgrasses, as their leaves are partially removed by regular mowing. Bertauski et al. (1997) reported cultivar differences in total N content of roots and NUE of was higher for 'Blacksburg' than for all cultivars except 'Eclipse'. Regression analyses indicated that plant NUE was closely related to NUE of leaf sheaths $(r=0.91)$, fibrous roots $(r=0.82)$, and rhizomes $(r=0.62)$ but not well related to NUE of leaf blades $(r=0.24)$. This observation suggests that the efficiency of $\mathrm{N}$ utilization by a turfgrass may depend on how efficiently photosynthate is translocated to the belowground organs.

The percentage of total plant $\mathrm{N}$ partitioned to fibrous roots, adventitious roots, rhizomes, or leaf sheaths, and the total $\mathrm{N}$ ratio of belowground to aboveground organs differed among the six cultivars (Table 3). 'Blacksburg' and 'Gnome' partitioned significantly more $\mathrm{N}$ to fibrous roots and less $\mathrm{N}$ to rhizomes than did 'Barzan'. 'Gnome' also had more $\mathrm{N}$ in leaf sheaths than did 'Barzan'. Leaf blades and thatch, which on average contained 37.6 and $21.1 \%$ of total plant $\mathrm{N}$, respectively, showed no significant cultivar variation in total $\mathrm{N}$ partitioning. Again, these results suggest that the differences in plant NUE among these cultivars were not due to differences in NUE of leaves, but largely to differences in their export of $\mathrm{N}$ assimilates to belowground organs. The fact that leaf blades and thatch had $>58 \%$ of the total plant $\mathrm{N}$ indicated the importance of returning turfgrass clippings to turf for maintaining the $\mathrm{N}$ balance.

Relationship between nitrate uptake and $N$ use efficiency. Total $\mathrm{N}$ recovered from the whole plant was significantly and positively correlated with total nitrate absorbed during the uptake experiment period (Fig. 2A). Furthermore, total nitrate uptake was better correlated with total $\mathrm{N}$ recovered from aboveground than belowground plant parts as indicated by $R^{2}$ and $F$ values (Fig. 2B and 2C). These results, along with the observation that $74 \%$ of total plant $\mathrm{N}$ was in the shoot materials, i.e., thatch, leaf blades, and sheaths (Table 3), are consistent with earlier observations that, under normal conditions, Kentucky bluegrass assimilates most of the absorbed nitrate in its shoots (Jiang and Hull, 1999).

Total plant dry weight was significantly and positively correlated with total nitrate uptake during the experimental period (Fig. $3 \mathrm{~A})$. Only a weak positive correlation $\left(R^{2}=\right.$ $0.27, P \leq 0.01$ ) was observed between total nitrate uptake and plant NUE expressed as grams dry matter per gram $\mathrm{N}$ present in the plant (Fig. 3B). When expressed as micromoles of nitrate absorbed per gram roots per day, NUR was significantly and negatively correlated with plant NUE (Fig. 4). This supports our assumption that even when NUE is determined for the whole plant, it will still show a negative relationship with NUR, and is in agreement with previous findings (Jiang and Hull, 1998). Because the nitrate uptake system is inducible by nitrate, and NUR of Kentucky bluegrass increases with increasing external nitrate concentrations up to $1 \mathrm{~mm}$ (Jiang and Hull, 1998; Wirén et al., 1997), high $\mathrm{N}$ fertilization rates will reduce NUE by saturating the nitrate uptake system. Increased nitrate uptake per unit root weight will promote nitrate export to shoots. This can inhibit 
photosynthate export to roots and reduce root growth because nitrate assimilation, an energyconsuming process, occurs primarily in the shoots (Jiang and Hull, 1999). Therefore, optimum rates of $\mathrm{N}$ should be applied to Kentucky bluegrass turf to promote efficient $\mathrm{N}$ utilization.

\section{Literature Cited}

Bertauski, A.F., J.M. Swiader, and D.J. Wehner. 1997. Dry weight production and nitrogen efficiency traits in Kentucky bluegrass cultivars in nutrient solution and soil. Crop Sci. 37:15481553.

Boot, R. G.A. 1989. The significance of size and morphology of root systems for nutrient acquisition and competition. p. 299-311. In: H. Lambers, M.L. Cambridge, H. Konings, and T.L. Pons (eds.). Causes and consequences of variation in growth rate and productivity of higher plants. SPB Academic Publishing, The Hague, The Netherlands.

Bowman, D.C., J.L. Paul, and W.B. Davis. 1989. Nitrate and ammonium uptake by nitrogen-deficient perennial ryegrass and Kentucky bluegrass turf. J. Amer. Soc. Hort. Sci. 114:421-426.
Cárdenas-Navarro, R., S. Adamowicz, and P. Robin. 1998. Diurnal nitrate uptake in young tomato (Lycopersicon esculentum Mill.) plants: Test of a feedback-based model. J. Exp. Bot. 49:721730.

Duff, D.T., H. Liu, R.J. Hull, and C.D. Sawyer 1997. Nitrate leaching from long established Kentucky bluegrass turf. Intl. Turfgrass Soc. Res. J. 8:175-186.

Eastin, E.F. 1978. Total nitrogen determination for plant material containing nitrate. Anal. Biochem. 85:591-594.

Ensign, R.D. and G.C. Weiser. 1975. Root and rhizome development of some Kentucky bluegrass and red fescue cultivars. Agron. J. 67:583-585.

Filleur, S. and F. Daniel-Vedele. 1999. Expression analysis of a high-affinity nitrate transporter isolated from Arabidopsis thaliana by differential display. Planta 207:461-469.

Harris, G.A. and G.S. Campbell. 1989. Automated quantification of roots using a simple image analyzer. Agron. J. 81:935-938.

Hoagland, D.R. and D.I. Arnon. 1950. The waterculture method for growing plants without soil. California Agr. Expt. Sta. Circ. 347.

Jiang, Z. and R.J. Hull. 1998. Interrelationships of nitrate uptake, nitrate reductase, and nitrogen use efficiency in selected Kentucky bluegrass cultivars. Crop Sci. 38:1623-1632.

Jiang, Z. and R.J. Hull. 1999. Partitioning of nitrate assimilation between shoots and roots of Kentucky bluegrass. Crop Sci. 39:746-754.

Liu, H., R.J. Hull, and D.T. Duff. 1993. Comparing cultivars of three cool-season turfgrasses for nitrate uptake kinetics and $\mathrm{N}$ recovery in the field. Intl. Turfgrass Soc. Res. J. 7: 546-552.

Liu, H., R.J. Hull, and D.T. Duff. 1997. Comparing cultivars of three cool-season turfgrasses for soil water $\mathrm{NO}_{3}^{-}$concentration and leaching potential. Crop Sci. 37:526-534.

McDonald, A.J.S., T. Ericsson, and C.M. Larsson. 1996. Plant nutrition, dry matter gain and partitioning at the whole-plant level. J. Exp. Bot 47: 1245-1253.

National Turfgrass Evaluation Programs. 1996. National Kentucky bluegrass test-1990 final report 1991-95, NTEP No. 96-11, U.S. Dept. of Agr., Agr. Res. Serv., Beltsville Agr. Res. Center, Beltsville, Md.

Sullivan, W.M., Z. Jiang, and R.J. Hull. 2000. Root morphology and its relationship with nitrate uptake in Kentucky bluegrass. Crop Sci. 40:765-772.

Wirén, V.N., S. Gazzarrini, and W.B. Frommer. 1997. Regulation of mineral nitrogen uptake in plants. Plant Soil 196:191-199. 